\title{
Chemical composition and energy value of guava and tomato wastes for broilers chickens at different ages
}

\author{
Rosa Cavalcante Lira ${ }^{1}$, Carlos Bôa-Viagem Rabello ${ }^{2}$, Edney Pereira da Silva ${ }^{2}$, Paulo \\ Vanderlei Ferreira ${ }^{1}$, Maria do Carmo Mohaupt Marques Ludke ${ }^{2}$, Edgenes Vital Costa $^{1}$
}

${ }^{1}$ Centro de Ciências Agrárias da Universidade Federal de Alagoas - UFAL.

2 Departamento de Zootecnia da Universidade Federal Rural de Pernambuco - UFRPE.

\begin{abstract}
The chemical composition and energy value of guava and tomato wastes for broilers at different ages were determined in this research. The metabolism assays were carried out by using the methodology of total excreta collection to calculate the chemical composition of wastes collected in different months. A total of 270 COBB broiler chicks was used: 150 in the period from 1 to 8 days of age (phase 1) and 120 chicks were used in the period from 10 to 17 days of age (phase 2). The trials were analyzed as completely randomized design with three treatments with five replications of 10 and 8 birds at the respective ages. The treatments consisted of different diets: one reference diet, one with $30 \%$ tomato meal and another with $20 \%$ guava meal, both partially replacing the reference diet. The values of the chemical composition of guava and tomato wastes varied according to the collection season. The chemical composition indicated that the wastes can be used in poultry feed, but with high crude fiber contents. The values of apparent metabolizable energy and nitrogen-corrected apparent metabolizable energy and of gross energy metabolizability coefficient of guava waste was not affected by the birds age, different from the result observed for tomato waste, whose digestibility coefficients and apparent metabolizable energy values varied among growing phases. The apparent metabolizable energy values (AME) for broilers form 1 to 8 and from 10 to 17 days of age were 1,331 and $1,358 \mathrm{kcal} / \mathrm{kg}$ for guava waste and from 2,351 to $2,465 \mathrm{kcal} / \mathrm{kg}$ for tomato waste.
\end{abstract}

Key Words: alternative food, chemical composition, metabolism

\section{Composição química e valores energéticos dos resíduos de goiaba e tomate para frangos corte em diferentes idades}

RESUMO - Objetivou-se determinar a composição química e os valores nergéticos dos resíduos de goiaba e de tomate para frangos de corte em diferentes idades. Os resíduos foram coletados em meses distintos e, posteriormente, determinada a composição química por meio de ensaios de metabolismo utilizando a metodologia da coleta total de excretas. Utilizaram-se 270 pintos de corte da linhagem COBB, sendo 150 no período de 1 a 8 dias e 120 no período de 10 a 17 dias de idade. Nos ensaios utilizou-se o delineamento inteiramente casualizado e três tratamentos com cinco repetições de 10 e 8 aves nas respectivas idades. Os tratamentos consistiram de três dietas: uma dieta referência, uma com 30\% de farelo de tomate e outra com 20\% de farelo de goiaba, ambas substituindo parte da ração referência. Os valores de composição química dos resíduos da goiaba e do tomate variaram quanto à época de coleta. Os resíduos apresentaram composição satisfatória para alimentação de aves, porém com altos teores de fibra bruta. Os valores de energia metabolizável o coeficiente de metabolizabilidade da energia bruta do resíduo da goiaba não sofreram influência da idade das aves. Para o resíduo de tomate os valores de energia metabolizável aparente e coeficiente de metabolização variaram entre as idades. Os valores de energia metabolizável aparente corrigida para pintos de corte de 1 a 8 e de 10 a 17 dias de idade foram de 1.331 e 1.358 kcal/kg para o resíduo de goiaba e de 2.351 e $2.465 \mathrm{kcal} / \mathrm{kg}$ para o resíduo de tomate.

Palavras-chave: alimento alternativo, composição química, metabolismo

\section{Introduction}

Most rations produced for monogastric animals are based on maize and soybean meal, which have a high cost. Therefore, the interest for alternative food has increased, especially for agro-industry wastes, since they generate a large quantity of byproducts that are great partial substitutes for these diets, decreasing the inclusion of maize and soybean meal.

In literature, information on the chemical composition of guava waste is limited, and the values mentioned are 47.04\% dry matter (Santos et al., 2009); 8.6 to $10.90 \%$ crude 
protein (Silva, 1999; Santos et al., 2009); 43.44 to 61.25\% crude fiber (Sales et al., 2004; Silva et al., 2009); and 48.81 to $81.95 \%$ neutral detergent fiber (Sales et al., 2004; Silva et al., 2009). The apparent metabolizable energy values (AME) and the nitrogen-corrected apparent metabolizable energy values (AMEn) described are 1,401 and 1,336 kcal/kg, respectively, for free-range broilers (Silva et al., 2009), and 1,882 and $1,900 \mathrm{kcal} / \mathrm{kg}$, respectively, for laying hens (Guimarães, 2007).

For tomato waste, the digestibility and energy values described for non-cecectomized and cecectomized roosters are 2,954 and 3,204 kcal/kg, respectively (Persia et al., 2003). Silva et al. (2009) reported AME values of 2,132 kcal/kg and AMEn values of 2,030 kcal/kg for free-range broilers. However, Loureiro et al. (2006) observed AME values of $3,393 \mathrm{kcal} / \mathrm{kg}$ and $\mathrm{AMEn}$ values of 2,806 kcal $/ \mathrm{kg}$, with laying hens. Variation in the chemical composition of tomato waste was observed by Cantarelli et al. (1993), with values from 14.6 to $29.6 \%$ ether extract; $42.8 \%$ linoleic acid and $18.2 \%$ oleic acid; 14.8 to $41.8 \%$ crude fiber; 2.0 to $9.6 \%$ mineral matter; and 22.9 to $36 \%$ crude protein.

The digestibility of food nutrients can be influenced by several factors, such as animal age, due to the maturation of the digestive system organs involved in the production of digestive enzymes, especially in the food passage rate (Nitsan et al., 1991).

The objective of this work was determined the nutritional and energy value of guava and tomato wastes for broilers at different ages.

\section{Material and Methods}

Collection of guava waste samples was made in June, August and September, and the tomato wastes were collected in September and October. The samples were obtained from the Tambau company, located in the municipality of Custódia, Pernambuco, Brazil.

Two metabolism assays were carried out in the period from February $12^{\text {th }}$ to the $28^{\text {th }}, 2005$, by the traditional method, using 150 Cobb chicks in the first experiment, 1 day of age on stage 1 ( 1 to 8 days), and 120 Cobb chicks in the second experiment, 10 days of age on stage 2 (10 to 17 days). The birds were placed in cells proper for metabolism studies, in a completely randomized experimental design, with three diets on each stage: one control diet, based on maize and soybean meal, formulated by using the food composition tables and the nutritional demands recommended by Rostagno et al. (2005); one test-diet with tomato waste replacing $30 \%$ of the control diet; and another test-diet with guava waste replacing $20 \%$ of the control diet; with five replications of 10 birds on stage 1 and 8 birds on stage 2 .

The experimental period lasted 8 days on each stage, the first 4 for adaptation to diet (guavas, ration and management) and 4 for for excreta collection, when animals were ad libitum fed twice a day (8:00 a.m. and 4:00 p.m.) and the intake, recorded. The excreta were collected every 12 hours directly from the trays (covered with plastic under the cages floor), weighed and stored in freezer at $-20^{\circ} \mathrm{C}$. After thawning, samples were weighed, homogenized and ovendried $\left(55^{\circ} \mathrm{C}, 72\right.$ hours). The guava and tomato wastes were sun-dried for 9 and 12 days, respectively, and analyzed to determine their gross energy and nutrients contents, as described by Silva \& Queiroz (2002). The metabolizable apparent energy (AME e AMEn) and the gross energy metabolization coefficient (CEMC) values, of each ration and of the food, were determined by using the formulas proposed by Matterson et al. (1965).

The variance analysis for the evaluation of the age effect on the variables was carried out using the statistical software Sisvar - System of statistical analyses - DEX/ UFLA (Ferreira, 2003).

\section{Results and Discussion}

The chemical composition, in some nutrients, of guava and tomato wastes presented variation between the periods in which the wastes were collected (Table 2). The gross energy contents varied from 5,171 (August) to 5,371 kcal/kg (June) and from 5,063 (October) to 5,329 kcal/kg (August) for guava and tomato wastes, respectively. These values are similar to the ones mentioned by Santos et al. (2009), of 5,389 kcal/kg for guava waste, and by Silva (1999), of 5,250 kcal/kg for tomato waste, from the same processing unit. These differences are mainly related to the variations in the crude protein and ether extract contents between the samples.

Regarding the dry matter, the variation for guava waste was from 44.42 (August) to 60.34\% (June), with a mean value of $50.38 \%$. For tomato waste, the variation was from 14.65 to $22.47 \%$, with a mean value of $18.56 \%$. Values close to the observed mean were obtained by Santos et al. (2009), of $47 \%$ for guava waste whereas for tomato waste, the observed DM contents were inferior to the ones obtained by Nardon \& Leme (1987), of 25.85\%.

The composition in crude protein of guava waste presented variation from 8.93 (August) to $10.09 \%$ (October), with a mean value of $9.61 \%$, and, for the tomato waste, the observed variation was from 17.21 (October) to 20.50\% 
Table 1 - Nutritional composition of the diets on stages from 1 to 8 days and from 10 to 17 days

\begin{tabular}{|c|c|c|}
\hline \multirow[t]{2}{*}{ Ingredient (\%) } & \multicolumn{2}{|c|}{ Stage (days) } \\
\hline & $1-8$ & $10-17$ \\
\hline Maize & 58.003 & 63.564 \\
\hline Soybean meal (45\% CP) & 35.284 & 30.930 \\
\hline Soy oil & 1.651 & 1.779 \\
\hline Dicalcium phosphate & 1.841 & 1.672 \\
\hline Limestone & 0.980 & 0.935 \\
\hline Salt & 0.460 & 0.415 \\
\hline DL-methionine 99 & 0.243 & 0.209 \\
\hline L-lysine $\mathrm{HCl} 78.8$ & 0.186 & 0.193 \\
\hline Mineral supplement ${ }^{1}$ & 0.050 & 0.050 \\
\hline Vitamin supplement & 1.200 & 0.100 \\
\hline Choline chloride $60 \%$ & 0.042 & 0.042 \\
\hline Bacitracin zinc & 0.050 & 0.050 \\
\hline Cygro $^{3}$ & 0.060 & 0.060 \\
\hline \multicolumn{3}{|l|}{ Calculated composition } \\
\hline Metabolizable energy (kcal/kg) & 2,900 & 3,000 \\
\hline Crude protein $(\%)$ & 21.360 & 19.840 \\
\hline Crude fiber (\%) & 3.2199 & 3.0705 \\
\hline Calcium (\%) & 0.9630 & 0.892 \\
\hline Available phosphorus (\%) & 0.4540 & 0.419 \\
\hline Sodium $(\%)$ & 0.2240 & 0.205 \\
\hline Total lysine (\%) & 1.2720 & 1.1700 \\
\hline Total methionine (\%) & 0.5682 & 0.5161 \\
\hline Total methionine + cystine $(\%)$ & 0.9030 & 0.8350 \\
\hline Total tryptophan (\%) & 0.2642 & 0.2392 \\
\hline Total threonine (\%) & 0.8195 & 0.7603 \\
\hline Choline added (mg/kg) & 187 & 187 \\
\hline \multicolumn{3}{|c|}{ 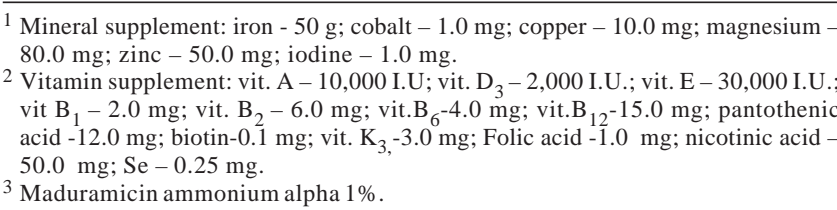 } \\
\hline
\end{tabular}

(August), with a mean of $18.85 \%$. These values are similar to the ones obtained by Santos et al. (2009) for guava waste, $10.90 \%$, and to the ones obtained by Silva (1999), $8.60 \%$, and they are inferior to the values obtained by Mccay \& Smith (1940) and Cantarelli et al. (1993) for tomato waste, from $22.9 \%$ to $36.8 \%$. For the ether extract values, the variation was from 9.96 (September) to $11.68 \%$ (June), with a mean value of $10.83 \%$ for guava waste, and from 5.73 (October) to
$11.17 \%$ (August) for tomato waste, with a mean value of $8.45 \%$. The values were similar to the ones obtained by Santos et al. (2009), $11.20 \%$, and Silva (1999), $11.30 \%$, for guava waste, inferior to the ones mentioned for tomato waste by Cantarelli et al. (1993) and Mccay \& Smith (1940), of 14.6 to $29.65 \%$, and close to the ones obtained by Kavamoto et al. (1971) and Kronka et al. (1971), of 2.11\% and $11.56 \%$, respectively.

The variation of neutral detergent fiber of guava waste was from 74.73 (October) to $84.30 \%$ (June), with a mean value of $78.96 \%$, close to the value observed by Silva (1999) for guava waste of $77.71 \%$; and the variation of the tomato waste was from 47.31 (October) to $53.17 \%$ (August), with a mean value of $50.24 \%$. The variation observed for ADF was from $60.27 \%$ (September) to $69.53 \%$ (June), with a mean value of $63.61 \%$ for guava waste, which is close to the one observed by Silva (1999) of 58.70\%. The variation observed for tomato waste was from $38.46 \%$ (October) to $43.92 \%$ (August), with a mean value of $41.19 \%$.

The hemicellulose presented variation from 13.71 (October) to $17.59 \%$ (September), with a mean value of $15.36 \%$ for guava waste, which is similar to the one reported by Silva (1999) of $17.03 \%$; and the variation for tomato waste was from 8.85 (October) to 9.25\% (August), with a mean value of $9.05 \%$.

For crude fiber, the values varied from 56.01 (October) to $60.08 \%$ (June), with a mean value of $57.42 \%$ for guava waste, which is below the value obtained by Santos et al. (2009) of 46.88\%. Regarding the tomato waste, the observed variation was from 35.86 (October) to 40.65\% (August), with a mean value of $38.25 \%$, which is similar to the value obtained by Cantarelli et al. (1993) of 41.8\%, and superior to the one found by Kavamoto et al. (1971) of 25.98\%.

The mineral matter presented variation from 2.32 (October) to $2.45 \%$ (June), with a mean value of $2.38 \%$ for guava waste, which is close to the one reported by Santos et al. (2009) of 2.21\%; and the variation for tomato waste

Table 2 - Chemical composition of guava and tomato waste (\% DM) ${ }^{1}$

\begin{tabular}{|c|c|c|c|c|c|c|c|}
\hline \multirow[t]{2}{*}{ Nutrient } & \multicolumn{4}{|c|}{ Guava waste } & \multicolumn{3}{|c|}{ Tomato waste } \\
\hline & June & August & September & Means & September & October & Means \\
\hline Dry matter (\%) & 60.34 & 44.42 & 46.38 & 50.38 & 22.47 & 14.65 & 18.56 \\
\hline Crude protein (\%) & 9.82 & 8.93 & 10.09 & 9.61 & 20.50 & 17.21 & 18.85 \\
\hline Ether extract (\%) & 11.68 & 9.96 & 10.86 & 10.83 & 11.17 & 5.73 & 8.45 \\
\hline Neutral detergent fiber (\%) & 84.30 & 77.86 & 74.73 & 78.96 & 53.17 & 47.31 & 50.24 \\
\hline Acid detergent fiber (\%) & 69.53 & 60.27 & 61.02 & 63.61 & 43.92 & 38.46 & 41.19 \\
\hline Hemicellulose (\%) & 14.77 & 17.59 & 13.71 & 15.36 & 9.25 & 8.85 & 9.05 \\
\hline Crude fiber (\%) & 60.08 & 56.17 & 56.01 & 57.42 & 40.65 & 35.86 & 38.25 \\
\hline Mineral matter (\%) & 2.45 & 2.36 & 2.32 & 2.38 & 3.78 & 4.81 & 4.29 \\
\hline Total carbohydrates (\%) & 77.10 & 76.02 & 76.82 & 76.65 & 64.55 & 72.25 & 68.40 \\
\hline Non-fibrous carbohydrates (\%) & 2.30 & 2.15 & 2.09 & 2.18 & 11.38 & 24.94 & 18.16 \\
\hline Crude energy (kcal/kg) & 5,371 & 5,171 & 5,229 & 5,257 & 5,329 & 5,063 & 5,196 \\
\hline
\end{tabular}

\footnotetext{
${ }^{1}$ Values expressed on dry matter basis.
} 
was from 3.78 (August) to $4.81 \%$ (October), with a mean value of $4.29 \%$, which is within the values from 2.0 to $9.6 \%$ observed by Cantarelli et al (1993).

The total carbohydrates of guava waste varied from 76.02 (Septmeber) to 77.10\% (June), with means of 76.65\%; while, for tomato waste, the variation was from 64.55 (August) to $72.25 \%$ (October), with means of $68.40 \%$. Regarding the non-fibrous carbohydrates, the observed variation for guava waste was from 2.09 (October) to $2.30 \%$ (June), with a mean value of $2.18 \%$, while, for tomato waste, the variation was from 11.38 (August) to $24.94 \%$ (October), with a mean value of $18.16 \%$.

The apparent metabolizable energy (AME), nitrogencorrected apparent metabolizable energy (AMEn) and gross energy metabolization coefficient (GEMC) values of the test-ration with the inclusion of $20 \%$ guava waste differed from the values of the control ration (Table 3 ) on both ages, indicating that there was a negative effect of the inclusion of $20 \%$ waste on the ration metabolizable energy and its metabolizability coefficients. Several authors have reported the effect of fiber on the digestibility of the nutrients of broiler rations. Kirchgessner et al. (1986) attributed the low digestibility of several food nutrients to an inverse relation with its acid detergent fiber content (ADF), which is probably the reason for the low values of energy use in this research.

The guava waste did not present significant differences as to the composition in AME, AMEn and GEMC in function of age. Respective values of $1,416 \mathrm{kcal} / \mathrm{kg}$, $1,331 \mathrm{kcal} / \mathrm{kg}$ and $27.10 \%$ were observed on the pre-initial stage, and of $1,392 \mathrm{kcal} / \mathrm{kg}, 1,358 \mathrm{kcal} / \mathrm{kg}$ and $26.65 \%$ on the initial stage. These values are considered satisfactory for guava waste inclusion on the calculation of rations for broilers. The guava waste gross energy metabolizability coefficient observed in this work was lower than that observed by Guimarães (2007), of $40.28 \%$, using the same inclusion level in the laying hen ration, and the ones reported by Sales et al. (2004) and Santos et al. (2009), with Nile tilapia, of $48.46 \%$ and $89.83 \%$, respectively.

The AME and AMEn values of guava waste determined in this research were also lower than the ones obtained by Guimarães (2007), 1,882 kcal/kg and 1,900 kcal/kg, respectively, in an assay on laying hens; however, these are expressed based on the natural matter.

The apparent and nitrogen-corrected apparent metabolizable energy values and the gross energy metabolizability coefficient (Table 4 ) of the test-ration with $30 \%$ tomato waste differed $(\mathrm{P}<0.05)$ from the reference ration on both stages, indicating that there was a negative effect of the inclusion of $30 \%$ tomato waste on the ration metabolizable energy and its metabolizability coefficient. As mentioned before, digestibility of the nutrients can be inversely related to the food ADF content (Kirchgessner et al., 1986) and this effect was probably observed in this research with the use of tomato waste.

Age of the birds did not influence the AMEn values of tomato waste, which were 2,351 and 2,465 kcal/kg for the preinitial and initial stages, respectively, indicating that there were no significant alterations on the nitrogen retention with advancing age.

Table 3 - Energy values and metabolizability values of the crude energy of guava waste and of the ration containing this byproduct (20\%)

\begin{tabular}{|c|c|c|c|c|c|}
\hline \multirow[t]{2}{*}{ Variables } & \multicolumn{2}{|c|}{ Age (days) } & \multirow[t]{2}{*}{ Means } & \multirow[t]{2}{*}{ F } & \multirow[t]{2}{*}{ CV (\%) } \\
\hline & 1 to 8 & 10 to 17 & & & \\
\hline \multicolumn{6}{|c|}{ Apparent metabolizable energy (kcal/kg of DM) } \\
\hline Reference ration & $3,418 \mathrm{~A}$ & 3,642A & & & \\
\hline Ration with $20 \%$ guava waste & $3,022 \mathrm{~B}$ & $3,220 \mathrm{~B}$ & & & \\
\hline Coefficient of variation (\%) & 2.96 & 2.59 & & & \\
\hline F value & $31.71 * *$ & $56.46 * *$ & & & \\
\hline Guava waste & $1,416 \mathrm{a}$ & $1,392 \mathrm{a}$ & 1,404 & $0.402 \mathrm{~ns}$ & 4.26 \\
\hline \multicolumn{6}{|c|}{ Apparent metabolizable energy corrected by nitrogen balance (kcal/kg of DM) } \\
\hline Reference ration & 3196A & $3470 \mathrm{~A}$ & & & \\
\hline Ration with $20 \%$ guava waste & $2,815 \mathrm{~B}$ & $3,096 \mathrm{~B}$ & & & \\
\hline Coefficient of variation (\%) & 1.86 & 2.57 & & & \\
\hline F value & $115.64 * *$ & $49.01 * *$ & & & \\
\hline Guava waste & $1,331 \mathrm{a}$ & $1,358 \mathrm{a}$ & 1,344 & $0.169 \mathrm{~ns}$ & 7.84 \\
\hline \multicolumn{6}{|c|}{ Gross energy metabolizability coefficient (\%) } \\
\hline Reference ration & $85.61 \mathrm{~A}$ & $92.81 \mathrm{~A}$ & & & \\
\hline Ration with $20 \%$ guava waste & $75.38 \mathrm{~B}$ & $83.10 \mathrm{~B}$ & & & \\
\hline Coefficient of variation (\%) & 2.17 & 2.59 & & & \\
\hline F value & $85.3 * *$ & $45.32 * *$ & & & \\
\hline Guava waste & $27.10 \mathrm{a}$ & $26.65 a$ & 26.87 & $0.374 \mathrm{~ns}$ & 4.27 \\
\hline
\end{tabular}

A,B Means followed by different letters on the column differ $(\mathrm{P}<0,05)$ by $\mathrm{F}$ test.

$\mathrm{a}, \mathrm{b}$ Means followed by different letters on the line differ $(\mathrm{P}<0,05)$ by $\mathrm{F}$ test.

** Significant at $1 \%$ probability; ns = not significant at $5 \%$ probability; CV $(\%)=$ coefficient of variation. 
Table 4 - Energy values and crude energy metabolizability coefficient of tomato waste and of the ration containing this byproduct (30\%), determined in broilers

\begin{tabular}{|c|c|c|c|c|c|}
\hline \multirow[t]{2}{*}{ Variables } & \multicolumn{2}{|c|}{ Age (days) } & \multirow[t]{2}{*}{ Means } & \multirow[t]{2}{*}{$\mathrm{F}$} & \multirow[t]{2}{*}{$\mathrm{CV}(\%)$} \\
\hline & 1 to 8 & 10 to 17 & & & \\
\hline \multicolumn{6}{|c|}{ Apparent metabolizable energy (kcal/kg of DM) } \\
\hline Reference ration & $3,418 \mathrm{~A}$ & $3,642 \mathrm{~A}$ & & & \\
\hline Ration with $30 \%$ tomato waste & $3,076 \mathrm{~B}$ & $3,298 B$ & & & \\
\hline Coefficient of variation (\%) & 2.24 & 1.89 & & & \\
\hline $\mathrm{F}$ value & $55.12 * *$ & $35.39 * *$ & & & \\
\hline Tomato waste & $2,283 a$ & $2,252 b$ & 2,267 & $21.03 * *$ & 3.47 \\
\hline \multicolumn{6}{|c|}{ Apparent metabolizable energy corrected by nitrogen (kcal/kg of DM) } \\
\hline Reference ration & 3196A & $3470 \mathrm{~A}$ & & & \\
\hline Ration with $30 \%$ tomato waste & $2,930 \mathrm{~B}$ & $3,168 \mathrm{~B}$ & & & \\
\hline Coefficient of variation (\%) & 2.56 & 1.80 & & & \\
\hline $\mathrm{F}$ value & $28.69 * *$ & $32.48 * *$ & & & \\
\hline Tomato waste & 2,351a & $2,465 \mathrm{a}$ & 2,408 & $0.169 \mathrm{~ns}$ & 7.84 \\
\hline \multicolumn{6}{|c|}{ Gross energy metabolizability coefficient (\%) } \\
\hline Reference ration & $85.61 \mathrm{~A}$ & $92.81 \mathrm{~A}$ & & & \\
\hline Ration with $30 \%$ tomato waste & $76.42 \mathrm{~B}$ & $78.58 \mathrm{~B}$ & & & \\
\hline Coefficient of variation (\%) & 2.24 & 2.02 & & & \\
\hline F value & $63.08 * *$ & $169.37 * *$ & & & \\
\hline Tomato waste & $45.11 \mathrm{a}$ & 49.89b & 47.50 & $21.0 * *$ & 3.47 \\
\hline
\end{tabular}

However, age of the birds did influence the AMEn values and the gross energy metabolizability coefficient (GEMC) of tomato waste, which were 2,283 and 2,525 kcal/kg and 45.11 and $49.89 \%$ on the pre-initial and initial stages, respectively. With the advancing age, the gross energy metabolizability coefficient and the ME values of tomato waste increased, which means that the tomato waste can be better used after the initial stage. This has probably occurred because, as the broilers age, their pancreas develop and the digestive enzymes production increases, thus improving the digestion capability and the food energy utilization (Sakomura et al., 2004).

The AME and AMEn values of tomato waste observed in this research were lower than the values obtained by Loureiro (2006), 3,393 and 2,806, respectively, in an assay with laying hens; however, in this research, the values are expressed based on the natural matter.

\section{Conclusions}

The chemical composition of guava and tomato waste varied according with the period of the collect. The average values of apparent metabolizable energy corrected for waste guava and tomato were: 1,344 and 2,408 kcal/kg, respectively.

\section{Acknowledgments}

The authors are grateful to the Fundação de Amparo à Pesquisa do Estado de Pernambuco (FACEPE) for partially granting this research; to TAMBAU company for donating the guava and tomato wastes; and to Próreitoria de Pesquisa e Pós-graduação da Universidade Federal Rural de Pernambuco for supporting the translation of this article. The authors thank Prof. Ronaldo Vasconcelos Farias Filho, Universidade Estadual do Sudoeste da Bahia (UESB) campus Itapetinga for experimental contributions.

\section{References}

CANTARELLI, P.R.; REGITANO-DARCE, M.A.B.; PALMA, E.R. Physicochemical characterístics and fatty acid composition of tomato seed oils from processing wastes. Scientia Agricola, v.50, n.1, p.117-120, 1993.

CORREIA, M.X.C.; COSTA, R.G.; SILVA, J.H.V. et al. Utilização de resíduo agroindustrial de abacaxi desidratado em dietas para caprinos em crescimento: digestibilidade e desempenho. Revista Brasileira de Zootecnia, v.35, n.4, p.1822-1828, 2006 (supl.).

FERREIRA, D.F. Programa SISVAR, Sistema de Análise de Variância, Versão 4,6 (Build 6,0), Lavras: DEX/UFLA, 2003.

GUIMARÃES, A.A.S. Utilização do resíduo de goiaba (Psidium guajava L.) na alimentação de poedeiras comerciais. 2007. 42f. Dissertação (Mestrado em Zootecnia) - Universidade Federal Rural de Pernambuco, Recife. 
KATANGOLE, J.B.D.; MARCH, B.E. Fat utilization in relation to intestinal fatty acid brinding protein and bile salts in chicks of different ages and different genetic sources. Poultry Science, v.59, p.819-827, 1980.

KAVAMOTO, E.T.; ROMEIRO, M.M.; BARBOSA, H.P. Emprego do subproduto da industrialização do tomate em rações de coelhos em crescimento e terminação. Boletim Indústria Animal, v.27/28 ( ${ }^{\circ}$ único), p.463-473, 1971.

KIRCHGESSNER, M.; KURZINGER, H.; SCHWARZ, F.J. Digestibility of crude nutrients in different feeds and estimation of their energy content of carp (Cyprinus carpio). Aquaculture, v.58, p.185-194, 1986.

KRONKA, R.N., SPERS, A.; SILVEIRA, J. J. N. et al. Subproduto da industrialização do tomate em rações de suínos em crescimentos e acabamento. Boletim Indústria Animal, v.27/28, nºúnico, p.101-107, 1971.

LOUREIRO, R.R.S.; RABELLO, C.B.V.; DUTRA JÚNIOR, W.M. et al. Valores de energia metabolizável e coeficientes de metabolização aparente da matéria seca e da energia bruta do farelo de tomate para poedeiras comerciais. In: REUNIÃO ANUAL DA SOCIEDADE BRASILEIRA DE ZOOTECNIA, 2006, João Pessoa. Anais... João Pessoa: SBZ, 2006. (CD-ROM).

McCAY, C.M.; SMITH, S.E. Tomato pomace in the diet. Science, v.91, n.2364, p.388-389, 1940.

MATTERSON, L.D. The metabolizable energy of feeds ingredient for chickens. Storrs, Connecticut: The Universyty of Connecticut: Agricultural experiment Station, 1965. 11p. (Research Report, 7).

NARDON, R.F.; LEME, R.P. Digestibilidade do subproduto do processamento por bovino. Boletim Indústria Animal, v.44, n.1, p.41-47, 1987.

NITSAN, Z.; DUNNING, E.A.; SIEGEL, P.B. Organ growth and digestive enzyme levels to fifteen days of age in lines of chickens differing in body weight. Poultry Science, v.70, p.2040-2048, 1991.

NASCIMENTO, A.H.; GOMES, P.C.; ROSTAGNO, H.S. et al. Valores de energia metabolizável de farinhas de penas e de vísceras determinados com diferentes níveis de inclusão e duas idades das aves. Revista Brasileira de Zootecnia, v.34, n.3, p.877-881, 2005.
PERSIA, M.E.; PARSONS, C.M.; SCHANG, M. et al. Nutritional evaluation of dried tomato seeds. Poultry Science, v.82, n.1, p.141-146, 2003.

ROSTAGNO H.S.; NASCIMENTO, A.H.; ALBINO, L.F.T. Aminoácidos totais e digestíveis para aves. In: SIMPÓSIO INTERNACIONAL SOBRE NUTRIÇÃO DE AVES, 2001, Viçosa, MG. Anais... Viçosa, MG: 2001. p.65-83.

ROSTAGNO H.S.; ALBINO, L.F.T.; DONZELE, J.L. et al. Composição de alimentos e exigências nutricionais Tabelas brasileiras para aves e suínos. Viçosa, MG: UFV, 2005. 141p.

SAKOMURA, N.K.; BIANCHI, M.D.; PIZZAURO JÚNIOR, J.M. et al. Efeito da idade dos frangos de corte na atividade enzimática e digestibilidade dos nutrientes do farelo de soja e da soja integral. Revista Brasileira de Zootecnia, v.33, n.4, p.924-935, 2004.

SALES, P.J.P.; FURUYA, W.M.; SANTOS, V.G. et al. Valor nutritivo dos farelos do subproduto industrial do tomate (Lycopersicum esculentum) e da goiaba (Psidium guajava) para tilápia do nilo (Oreochromis niloticus). In: REUNIÃO ANUAL DA SOCIEDADE BRASILEIRA DE ZOOTECNIA, 41., 2004, Campo Grande. Anais... Campo Grande: SBZ, 2004. (CD-ROM).

SANTOS, E.L.; LUDKE, M.C.M.M.; BARBOSA, J.M. et al. Digestibilidade aparente do farelo de coco e do resíduo de goiaba para tilápia do Nilo. Caatinga, v.22, n.2, p.175-180, 2009.

SILVA, J.D.A. Composição química e digestibilidade in situ da semente de goiaba (Psidium guajava L.). 1999. $34 \mathrm{f}$ Dissertação (Mestrado em Produção Animal) - Universidade Federal Rural de Pernambuco, Recife.

SILVA, D.J.; QUEIROZ, A.C. Análise de alimentos: métodos químicos e biológicos. 3.ed. Viçosa, MG:UFV, 2002. 235p.

SILVA, E.P.; SILVA, D.A.T.; RABELLO, C.B. et al. Características físico-químicas, energéticas e nutricional dos resíduos de goiaba e tomate para frangos de corte de crescimento lento. Revista Brasileira de Zootecnia, v.38, n.6, p.1051-1058, 2009.

WHITEHEAD, G.C.; FISCHER, C. The utilization of various fats by turkey of different ages. British Poultry Science, v.38, n.1, p.28-35, 1982 